\title{
BOVINE HERPESVIRUS 5 DETECTION BY VIRUS ISOLATION IN CELL CULTURE AND MULTIPLEX-PCR IN CENTRAL NERVOUS SYSTEM FROM CATTLE WITH NEUROLOGICAL DISEASE IN BRAZILIAN HERDS
}

\author{
Marlise Pompeo Claus; Alice Fernandes Alfieri; Kerlei Cristina Médici; Michele Lunardi; Amauri Alcindo Alfieri* \\ Laboratório de Virologia Animal, Departamento de Medicina Veterinária Preventiva, Centro de Ciências Agrárias, Universidade \\ Estadual de Londrina, Londrina, PR, Brasil
}

Submitted: January 04, 2007; Returned to authors for corrections: April 02, 2007; Approved: July 27, 2007.

\begin{abstract}
Bovine herpesvirus 5 (BoHV-5) is an important cause of meningoencephalitis in young and adult cattle. The multiple etiology of neurological disturbances in cattle makes the quick and conclusive diagnosis of BoHV5 infection important for animal and public health, mainly because of herbivore rabies that is endemic in Brazilian cattle herds. The objective of this retrospective study was to use a multiplex-polymerase chain reaction (multiplex-PCR) for BoHV-5 and BoHV-1 glycoprotein C gene detection from stored central nervous system (CNS) tissue fragments of cattle with neurological clinical signs. Forty-seven frozen CNS samples of young and adult cattle from 31 herds in three Brazilian geographical regions (South, Southeast, and Centerwest) were evaluated. Eighteen (38.3\%) of these CNS samples were BoHV-positive by virus isolation in cell culture. By multiplex-PCR 30 (63.8\%) CNS samples were BoHV-5 positive. All 18 positive samples by virus isolation were confirmed as BoHV-5 by the multiplex-PCR, that provided a increase of $25.5 \%(12 / 47)$ in the BoHV-5 diagnosis rate. BoHV-1 was not detected in any CNS sample. This retrospective study demonstrated the wide regional distribution of BoHV-5 infection in Brazilian cattle herds since positive results were obtained in CNS samples of cattle with neurological disease from Paraná, São Paulo, Minas Gerais, Mato Grosso, and Mato Grosso do Sul States.
\end{abstract}

Key words: cattle, meningoencephalitis, bovine herpesvirus 5, multiplex-PCR

\section{INTRODUCTION}

The diseases that cause neurological disturbances in dairy and beef cattle can be responsible for significant economic losses due to high death rates. Infectious agents such as virus, bacteria, and protozoa can be involved in central nervous system (CNS) diseases in cattle (17). A range of very similar clinical signs, imply that definitive diagnosis can only be made with the utilization of laboratory techniques that identify the etiological agent (3). In Brazil, herbivore rabies occurs throughout the country (16). Then, in addition to their importance for animal health, diseases that affect the CNS of cattle also have importance on public health making it very important in the elaboration of conclusive laboratorial diagnosis.
Bovine herpesvirus 5 (BoHV-5), classified in the Herpesviridae family, Alphaherpesvirinae sub-family, is a neurovirulent strain of bovine herpesvirus (BoHV) that is the etiological agent of bovine non-suppurative meningoencephalitis (12). BoHV-5 has been detected in various regions of the world, and also in Brazil $(10,20,22)$ causing a neurological disease in young and adult cattle. The most characteristic signs of the infection include anorexia, respiratory and ocular secretions, muscle trembling, circling, opisthotonus, nystagmus, teeth grinding, ataxia, and seizures (4).

BoHV-5 can be detected in the CNS of cattle with neurological signs by virus isolation in cell culture and strain characterization with anti-BoHV-5 monoclonal antibodies and/ or by molecular techniques $(13,22)$. Virus isolation is a

*Corresponding Author. Mailing address: Rodovia Celso Garcia Cid - Caixa Postal 6001 - cep 86051-990 Londrina, PR - Brasil. Tel.: (43) 3371-4714.

E-mail: alfieri@uel.br 
troublesome technique that requires the maintenance of cell cultures and a long time to obtain conclusive results. Furthermore, the need of the infectiousness of the virus that can be reduced by collection, transport and storage conditions of biological samples suggest that false-negative results can be generated in many situations. On the other hand, molecular techniques such as PCR detect the viral DNA from different types of specimens, are highly sensitive, specific, fast and do not require the infectiousness of the viral particle (18).

This retrospective study describes the use of the multiplexPCR assay for BoHV-5 and BoHV-1 detection in a CNS fragments collection, previously assessed in cell culture, from cattle with clinical neurological signs in seven Brazilian states.

\section{MATERIALS AND METHODS}

\section{Virus and Cells}

MDBK (Madin Darby bovine kidney) cells were amplified in Dulbecco's modified essential medium (D-MEM, Gibco BRL, USA) supplemented with $10 \%$ fetal bovine serum (FBS, Gibco BRL, USA), $55 \mu \mathrm{g} / \mathrm{ml}$ gentamicine (Sigma Co., USA) and 2.5 $\mu \mathrm{g} / \mathrm{ml}$ amphotericin B (Sigma Co., USA). The Los Angeles strain (LA) of BoHV-1 and the field strain AA 01, characterized as BoHV-5 by immunoperoxidase with monoclonal antibodies (19) and by Restriction Fragment Length Polymorphism (RFLP) analysis of the viral DNA (9), were used as positive controls in the multiplex-PCR technique. The MDBK cells were used for both, amplification of the LA and AA 01 virus strains, and for attempts of BoHV-5 isolation from clinical specimens.

\section{CNS fragments}

From 1999 to 2004, 47 CNS samples, including fragments of brain, cerebellum, and brainstem were submitted for viral diagnosis. The samples were collected in 31 outbreaks of neurological disease in young and adult animals in dairy $(n=5)$ and beef $(n=26)$ cattle herds from seven Brazilian states (Paraná, São Paulo, Minas Gerais, Goiás, Mato Grosso, Mato Grosso do Sul, and Rondônia). Infection by the rabies virus was excluded in all cases by the negative results in the diagnosis performed by direct immunofluorescence and by inoculation in mice according to the standard procedure in a reference laboratory.

\section{Virus isolation in cell culture}

Suspension (10-20\% w/v) of the CNS fragments in phosphate-buffered saline $\mathrm{pH} 7.2(137 \mathrm{mM} \mathrm{NaCl} ; 3 \mathrm{mM} \mathrm{KCl}$; $8 \mathrm{mM} \mathrm{Na}_{2} \mathrm{HPO}_{4} ; 15 \mathrm{mM} \mathrm{KH}_{2} \mathrm{PO}_{4}$ ) was centrifuged at $3000 \mathrm{~g}$ for $15 \mathrm{~min}$ at $4^{\circ} \mathrm{C}$. A fraction of the supernatant was immediately used for virus isolation in cell culture and the other was stored at $-20^{\circ} \mathrm{C}$ for subsequent analysis. Aliquots of $500 \mu \mathrm{l}$ of the supernatant were treated with gentamicine $(55 \mu \mathrm{g} / \mathrm{ml})$ and amphotericin B $(2.5 \mu \mathrm{g} / \mathrm{ml})$ and inoculated in MDBK cells maintained in FBS-free D-MEM in a roller system for attempted virus isolation. All specimens were inoculated in cell culture for at least three consecutive blind passages. In the samples that induced cytopathic effect in cell culture the presence of BoHV was evaluated by a semi-nested PCR to detect the BoHV glycoprotein B gene (23).

\section{Nucleic Acid Extraction}

For the nucleic acid extraction aliquots of all $47 \mathrm{CNS}$ fragments that had been kept in storage at $-20^{\circ} \mathrm{C}$ for more than five years were used. Frozen suspensions aliquots (500 $\mu \mathrm{l})$ of each sample were treated with sodium dodecyl sulphate (SDS) and Proteinase K (Invitrogen, Life Technologies, USA) at final concentration of $1 \%$ and $0.2 \mathrm{mg} / \mathrm{ml}$, respectively. After homogenization, the samples were kept at $56^{\circ} \mathrm{C}$ for $30 \mathrm{~min}$. For DNA extraction a combination of phenol/chloroform/isoamyl alcohol and silica/guanidine isothiocyanate methods (1) was performed with slight modification. Briefly, the samples were treated with an equal volume of phenol/chloroform/isoamyl alcohol (25:24:1), homogenized and heated at $56^{\circ} \mathrm{C}$ for $15 \mathrm{~min}$ (21). After centrifugation at $10,000 \mathrm{~g}$ for $10 \mathrm{~min}$ the aqueous phase was processed with silica/guanidine isothiocyanate (5). The DNA was eluted in $50 \mu \mathrm{l}$ ultrapure (MilliQ ${ }^{\circledR}$ ) sterile water and kept at $-20^{\circ} \mathrm{C}$ until use. Aliquots of ultrapure sterile water were included as negative controls in all the DNA extraction procedures.

\section{Multiplex-PCR}

Multiplex-PCR was carried out according to Claus (6). Briefly, the reaction was performed in a solution containing 5 $\mu l$ of the extracted DNA and $45 \mu \mathrm{l}$ of PCR-mix consisting of 20 pmol of each primers B1 (5'CAACCG AGACGGAAA GCTCC $3^{`}$ 'nt 185-204); B5 (5'CGG ACGAGACGC CCTTGG 3'- nt 322339) and Bcon [5 'AGT GCACGT ACA GCG GCT CG 3'nt 519538 (BoHV-1) and nt 461-480 (BoHV-5)]; $1.6 \mathrm{mM}$ of each dNTP (Invitrogen ${ }^{\mathrm{TM}}$ Life Technologies, USA); 2.5 units Platinum Taq DNA polymerase (Invitrogen ${ }^{\mathrm{TM}}$ Life Technologies, USA); 1x PCR buffer (20 mM Tris-HCl pH 8.4 and $50 \mathrm{mM} \mathrm{KCl}$ ); 1.5 $\mathrm{mM} \mathrm{MgCl} ; 8 \%$ dimetilsulfoxide (DMSO, Sigma Co., USA) and ultrapure sterile water to a final volume of $50 \mathrm{ml}$. Amplification was performed in a thermocycler (PTC 200, MJ Research Co., USA) according to the following conditions of time and temperature: an initial step of $3 \mathrm{~min}$ at $94^{\circ} \mathrm{C}$ followed by 40 cycles of $1 \mathrm{~min} / 94^{\circ} \mathrm{C} ; 1 \mathrm{~min} / 58^{\circ} \mathrm{C}, 1 \mathrm{~min} / 72^{\circ} \mathrm{C}$ and a final extension step of $7 \mathrm{~min} / 72^{\circ} \mathrm{C}$.

The amplified products with 159 base pairs (bp) for the BoHV-5 and 354 bp for the BoHV-1 were analysed by electrophoresis in 2\% agarose gel in TBE buffer $\mathrm{pH} 8.4(89 \mathrm{mM}$ Tris; $89 \mathrm{mM}$ boric acid; $2 \mathrm{mM}$ EDTA) at constant voltage (90V) for aproximately $45 \mathrm{~min}$, stained with ethidium bromide $(0.5 \mu \mathrm{g} /$ $\mathrm{ml}$ ), and visualized under UV light. 


\section{Statistical analysis}

The kappa statistic ( $\kappa)$ was calculated to evaluate the agreement between virus isolation in cell culture technique and multiplex-PCR assay. When $\kappa=0$ there is no agreement, $\kappa<0.3$ the agreement is poor, $\kappa$ between 0.3 and $<0.5$ is acceptable, $\kappa$ between 0.5 and 0.7 is good, and $\kappa>0.7$ is excellent (15). A value of $p<0.05$ was considered statistically significant. The statistical analysis was made by using the EpiInfo 6.04 program (8).

\section{RESULTS AND DISCUSSION}

The BoHV isolation in cell culture was obtained in 38.3\% (18/47) of the assessed CNS samples. A 159 bp DNA fragment was amplified by multiplex-PCR in 30 (63.8\%) CNS samples collected from dairy $(n=13)$ and beef $(n=17)$ cattle herds (Fig. 1). All 18 positive samples in cell culture were also positive by multiplex-PCR for the BoHV-5. A $354 \mathrm{bp}$ DNA fragment of the BoHV-1 glycoprotein $\mathrm{C}$ gene was not amplified in any CNS sample. The agreement between the two assays was good $(\kappa=0.52 ; p<0.001)$. Table 1 shows the distribution of the concordant and discordant results obtained between the virus isolation in cell culture technique and multiplex-PCR assay.

During this retrospective study the use of multiplex-PCR demonstrated a increase in the BoHV-5 diagnosis rate in $\mathrm{CNS}$ fragments from cattle with neurological disease, compared with the results obtained by virus isolation in cell culture technique.

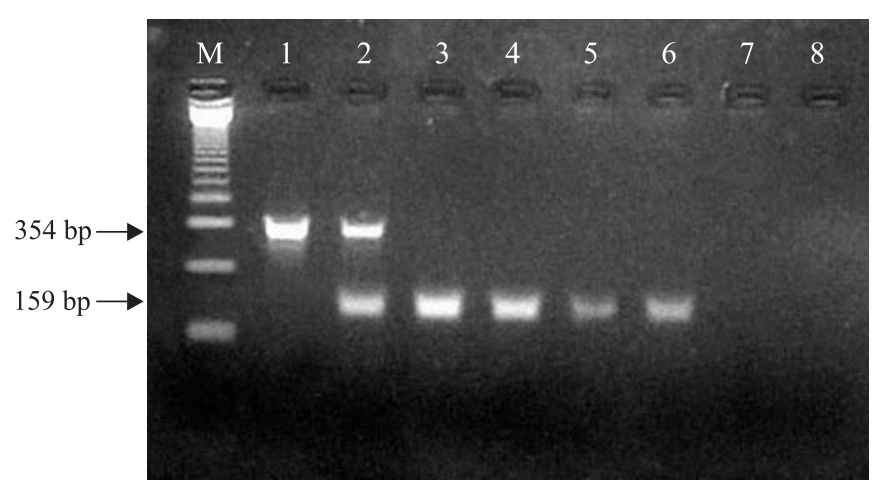

Figure 1. Ethidium bromide stained $2 \%$ agarose gel electrophoresis of the amplified products by multiplex-PCR for the BoHV-1 (354 bp) and BoHV-5 (159 bp) glycoprotein C gene in central nervous system (CNS) from cattle with neurological disease. Lane M: 123 bp ladder (Invitrogen, USA); Lane 1: BoHV-1 (LA strain); Lane 2: Mix of BoHV-1 (LA strain) and BoHV-5 (AA 01 strain); Lane 3: BoHV-5 (AA01 strain); Lane 4: CNS sample positive for BoHV by virus isolation in cell culture; Lane 5 and 6: CNS samples negative for BoHV by virus isolation in cell culture; Lane 7: CNS sample negative for BoHV by virus isolation in cell culture and multiplex-PCR; Lane 8: Negative control of DNA extraction (ultrapure sterile water).
Table 1. Distribution of the positive and negative results for bovine herpesvirus 5 obtained by virus isolation in cell culture and multiplex-PCR techniques in central nervous system samples from cattle with neurological disease.

\begin{tabular}{lccc}
\hline \multirow{2}{*}{ Multiplex-PCR } & \multicolumn{2}{c}{ Virus isolation } & \multirow{2}{*}{ Total } \\
\cline { 2 - 3 } & Positive & Negative & \\
\hline Positive & 18 & 12 & 30 \\
Negative & 0 & 17 & 17 \\
\hline Total & 18 & 29 & 47 \\
\hline$\kappa=0.52 ; p<0.001$. & & &
\end{tabular}

In $25.5 \%(12 / 47)$ of the samples, where BoHV isolation in cell culture was not possible in previous studies, the use of multiplex-PCR detected the glycoprotein C gene of the BoHV-5 in CNS fragments stored at freezing temperatures, some for up to five years.

The greater number of the BoHV-5 positive samples obtained with the use of multiplex-PCR was mainly due to the requirement of the infectiousness of the virus for isolation in cell culture. Due to the specimens collection under field conditions the virus can be inactivated (24). This characteristic is very important in veterinary medicine, especially for cattle farms in Brazil, because specimens collected in the field for diagnosis are often improperly conserved and require a long transport time from the farms to the laboratory.

The results of this study showed that the use of only one diagnostic method for BoHV-5, and in particular virus isolation in cell culture may result in the generation of false-negative results. Besides reducing the efficiency of the diagnosis, the false-negative results also induce incorrect information that has direct consequences on epidemiological studies and can also be responsible for the non-adoption of control and prophylaxis measures. Nevertheless, virus isolation in cell culture, especially in a research laboratory, is an essential technique because it supplies the availability of the wild-type virus strains for antigenic and molecular analysis.

Ely (11) also described that the PCR assay was more sensitive than virus isolation for diagnosis of BoHV infection. This virus was isolated in only one of the five bovine brain samples submitted to cell culture, while by PCR all samples were positive. A greater number of BoHV-5 positive samples were also detected by the PCR technique in nasal swabs from experimentally infected cattle (2). Takiuchi (24) used virus isolation and semi-nested PCR to detect BoHV-1 in organs fragments of aborted fetuses and found positive results in 5 and 14 samples, respectively.

In the present study the BoHV-5 was identified in CNS specimens from cattle herds in five Brazilian States (Mato Grosso 
do Sul, Mato Grosso, Minas Gerais, São Paulo, and Paraná). Negative results were obtained only from samples obtained from Goiás and Rondônia States from which only one and two samples, respectively, were analyzed.

In Brazil, meningoencephalitis by BoHV-5 was also been described in some of these States, and others such as Rio de Janeiro and Rio Grande do Sul $(7,14,20,22)$ indicating that this virus is widely distributed in cattle herds in geographically distant Brazilian regions.

The remainder 17 (36.2\%) multiplex-PCR negative-CNS specimens from cattle with neurological signs may result from other common diseases that cause neurological disturbances in Brazilian cattle herds, such as polyencephalomalacia or plant intoxications, that were not assessed in this study. Another aspect to be reported is the set of CNS fragments with low virus titre or even without virus. BoHV-5 is not uniformly distributed in all the CNS, and the processing of fragments from different CNS regions are very important when etiological diagnostic techniques are used (4).

In this study only BoHV-5 was identified by multiplex-PCR. Souza (22) using monoclonal antibodies to characterize the type of BoHV isolated from clinical specimens related that all samples from cattle with encephalitis presented BoHV-5 antigenic profile. However, Ely (11) characterized a virus strain from cattle with encephalitis as BoHV-1.

With the samples used in the present study the category of cattle (suckling/weaned) where the infection was most frequent could not be determined. The distribution of the positive results for BoHV-5 obtained by multiplex-PCR showed that $50 \%(15 / 30)$ of the positive samples were from suckling calves (21 days to 5 months). The others 15 (50\%) positive samples were obtained from weaned animals, and was most frequent in 15 to 24 months old cattle. Two cows with 5-years-old and other one with 6-years-old were the older animals with BoHV-5 infection (Table 2).

This retrospective study showed the importance of the use of alternative diagnostics methods that enable the BoHV-5 identification even in situations where there are failures of collection, storage, and transport of specimens. It was also shown that BoHV-5 is an important pathogen of encephalitis in cattle and due to its wide geographical distribution in Brazil, this virus should be included in the differential diagnosis of disease.
Table 2. Cell culture isolation and multiplex-PCR results for bovine herpesvirus 5 detection in central nervous system samples from cattle with neurological

\begin{tabular}{|c|c|c|c|c|c|c|c|c|}
\hline \multicolumn{3}{|c|}{ outbreak } & \multirow[t]{2}{*}{ bred } & \multirow[t]{2}{*}{ age } & \multicolumn{2}{|c|}{$\mathrm{n}^{\circ}$ animals } & \multicolumn{2}{|c|}{$\begin{array}{c}\text { positives } \\
\text { samples }\end{array}$} \\
\hline $\mathrm{n}^{\circ}$ & year & state & & & dead & evaluated & $\mathrm{VICC}^{(\#)}$ & M-PCR \\
\hline 01 & 1999 & MS & Nelore & $24 \mathrm{~m}$ & 21 & 4 & 4 & 4 \\
\hline 02 & 1999 & $\mathrm{MG}$ & Holstein & $60 \mathrm{~m}$ & 1 & 1 & 1 & 1 \\
\hline 03 & 1999 & SP & Holstein & $21 \mathrm{~d}$ & 9 & 2 & 2 & 2 \\
\hline 04 & 1999 & SP & Holstein & $60 d$ & 11 & 3 & 3 & 3 \\
\hline 05 & 2000 & MT & Nelore & $45 \mathrm{~d}$ & NI & 1 & 1 & 1 \\
\hline 06 & 2000 & MT & Nelore & $70 \mathrm{~d}$ & NI & 1 & 1 & 1 \\
\hline 07 & 2000 & MS & Canchim & $4 \mathrm{~m}$ & NI & 1 & - & - \\
\hline 08 & 2000 & SP & Nelore & $20 \mathrm{~d}$ & NI & 2 & - & - \\
\hline 09 & 2001 & MS & Nelore & $24 \mathrm{~m}$ & NI & 1 & - & - \\
\hline 10 & 2001 & PR & 1/2 A.Angus & $40 \mathrm{~m}$ & 1 & 1 & - & - \\
\hline 11 & 2001 & MT & Nelore & $15 \mathrm{~m}$ & 11 & 1 & 1 & 1 \\
\hline 12 & 2001 & MS & 1/2 Marchigiana & $22 \mathrm{~m}$ & 5 & 2 & 2 & 2 \\
\hline 13 & 2001 & MS & 1/2 Marchigiana & $24 \mathrm{~m}$ & 5 & 2 & 2 & 2 \\
\hline 14 & 2001 & MG & 1/2 A.Angus & $18 \mathrm{~m}$ & 20 & 1 & - & - \\
\hline 15 & 2001 & PR & Nelore & $18 \mathrm{~m}$ & 4 & 1 & - & 1 \\
\hline 16 & 2001 & RO & Nelore & $60 \mathrm{~m}$ & 2 & 1 & - & - \\
\hline 17 & 2001 & PR & 1/2 Limousin & $15 \mathrm{~m}$ & 3 & 1 & - & 1 \\
\hline 18 & 2002 & PR & Simenthal & $30 \mathrm{~m}$ & 5 & 1 & - & - \\
\hline 19 & 2002 & $\mathrm{GO}$ & 1/2 Simenthal & $18 \mathrm{~m}$ & 1 & 1 & - & - \\
\hline 20 & 2002 & PR & Nelore & $42 \mathrm{~m}$ & 3 & 1 & - & - \\
\hline 21 & 2002 & RO & Nelore & $72 \mathrm{~m}$ & 3 & 1 & - & - \\
\hline 22 & 2002 & PR & Limousin & $5 \mathrm{~d}$ & NI & 1 & - & - \\
\hline 23 & 2002 & MG & Simenthal & $60 d$ & 2 & 1 & - & 1 \\
\hline 24 & 2003 & MT & Nelore & $22 \mathrm{~m}$ & 4 & 1 & 1 & 1 \\
\hline 25 & 2003 & MS & Nelore & $18 \mathrm{~m}$ & 1 & 1 & - & - \\
\hline 26 & 2003 & MT & Nelore & $36 \mathrm{~m}$ & 6 & 1 & - & - \\
\hline 27 & 2003 & PR & Nelore & $24 \mathrm{~m}$ & 4 & 1 & - & 1 \\
\hline 28 & 2003 & PR & Nelore & $40 \mathrm{~m}$ & 1 & 1 & - & - \\
\hline 29 & 2004 & MG & Holstein & $6 \mathrm{~m}$ & NI & 2 & - & - \\
\hline 30 & 2004 & PR & Swiss Brown & $4 \mathrm{~m}$ & 7 & 7 & - & 7 \\
\hline 31 & 2004 & PR & Nelore & $24 \mathrm{~m}$ & 8 & 1 & - & 1 \\
\hline Total & & & & & & 47 & 18 & 30 \\
\hline
\end{tabular}

d: days; m: months; 1/2: half-blood; NI - not informed; (\#): Virus isolation in cell culture.

neurological disturbances in young and adult animals from beef and dairy cattle herds.

\section{ACKNOWLEDGEMENTS}

The authors thank the Brazilian Institutes CNPq, CAPES, FINEP, and Fundação Araucária (FAP/PR) for the financial support. Alfieri, A.A. and Alfieri, A.F. are recipient of CNPq fellowship. 


\section{RESUMO}

\section{Detecção do herpesvírus bovino 5 por isolamento viral e multiplex-PCR em SNC de bovinos com doença neurológica em rebanhos brasileiros}

O herpesvírus bovino 5 (BoHV-5) é um importante agente etiológico de meningoencefalite em bovinos jovens e adultos. A etiologia múltipla dos distúrbios neurológicos em bovinos torna o diagnóstico conclusivo do BoHV-5 importante tanto em termos de sanidade animal quanto de saúde pública, principalmente pela característica endêmica da raiva dos herbívoros nos rebanhos bovinos brasileiros. $\mathrm{O}$ objetivo desse estudo retrospectivo foi utilizar a reação em cadeia da polimerase (multiplex-PCR) para a detecção do gene da glicoproteína C do BoHV-5 e do BoHV-1 em fragmentos estocados de sistema nervoso central (SNC) de bovinos com sinais clínicos neurológicos. Foram avaliadas 47 amostras congeladas de fragmentos de SNC de bovinos jovens e adultos pertencentes a 31 rebanhos de três regiões geográficas brasileiras (Sul, Sudeste e Centro-oeste). Por meio do isolamento viral em cultivo celular foi possível o isolamento do BoHV em 18 $(38,3 \%)$ amostras. Pela técnica de multiplex-PCR 30 (63,8\%) amostras de SNC foram positivas para o BoHV-5. Todas as 18 amostras positivas no isolamento viral foram confirmadas como BoHV-5 pela multiplex-PCR, proporcionando um incremento na taxa de diagnóstico do BoHV-5 de 25,5\% (12/47). Em nenhuma das amostras avaliadas foi possível a identificação do BoHV-1 pela multiplex-PCR. Esse estudo retrospectivo demonstrou a ampla distribuição da infecção pelo BoHV-5 nos rebanhos bovinos brasileiros uma vez que resultados positivos foram obtidos em amostras de SNC colhidas de bovinos com doença neurológica, provenientes dos estados do Paraná, São Paulo, Minas Gerais, Mato Grosso e Mato Grosso do Sul.

Palavras-chave: bovino, meningoencefalite, herpesvírus bovino 5, multiplex-PCR

\section{REFERENCES}

1. Alfieri, A.F.; Alfieri, A.A.; Barreiros, M.A.B.; Leite, J.P.G.; Richtzenhain, L.J. (2004). G and P genotypes of group A rotavirus strains circulating in calves in Brazil, 1996-1998. Vet. Microbiol., 99: 167-173.

2. Ashbaugh, S.E.; Thompson, K.E.; Belknap, E.B.; Schultheiss, P.C.; Chowdhury, S.; Collins, J.K. (1997). Specific detection of shedding and latency of bovine herpesvirus 1 and 5 using a nested polymerase chain reaction. J. Vet. Diag. Invest., 9: 387-394.

3. Barros, C.S.L.; Marques, G.H.F. (2003). Procedimentos para o Diagnóstico das Doenças do Sistema Nervoso Central de Bovinos. Departamento de Defesa Animal, Ministério da Agricultura, Pecuária e Abastecimento (MAPA), Brasília, p.1-50.

4. Belknap, E.B.; Collins, J.K.; Ayers, V.K.; Schultheiss, P.C. (1994). Experimental infection of neonatal calves with neurovirulent bovine herpesvirus type 5 (BHV-5). Vet. Pathol., 31: 358-365.

5. Boom, R.; Sol, C.J.A.; Salimans, M.M.M.; Jansen, C.L.; Wertheimvan Dillen, P.M.E.; Noordaa, J. van der. (1990). Rapid and simple method for purification of nucleic acids. J. Clin. Microbiol., 28 495-503.

6. Claus, M.P.; Alfieri, A.F.; Folgueras-Flatschart, A.V.; Wosiacki, S.R.; Médici, K.C.; Alfieri, A.A. (2005). Rapid detection and differentiation of bovine herpesvirus 1 and 5 glycoprotein $\mathrm{C}$ in clinical specimens by multiplex-PCR. J. Virol. Meth., 128: 183-188.

7. Colodel, E.M.; Nakazato, L.; Weiblen, R.; Mello, R.M.M.; Silva, R.R.P.; Souza, M.A.; Filho, J.A.O.; Caron, L. (2002). Meningoencefalite necrosante causada por herpesvírus bovino no Estado de Mato Grosso, Brasil. Ciência Rural, 32: 293-298.

8. Dean, A.G.; Dean, J.A.; Coulombier, D.; Burton, A.H.; Brendel, K.A.; Smith, D.C.; Dicker, R.C.; Sullivan, K.M.; Fagan, R.F.; Arne, T.G (1997). Epi Info versão 6.04b disponível em http://www.cdc.gov/ epiinfo/.

9. D'Arce, R.C.F.; Almeida, R.S.; Silva, T.C.; Franco, A.C.; Spilki, F.; Roehe, P.M.; Arns, C.W. (2002). Restriction endonuclease and monoclonal antibody analysis of Brazilian isolates of bovine herpesvirus types 1 and 5. Vet. Microbiol., 88: 315-324.

10. D'Offay, J.M.; Mock, R.E.; Fulton, R.W. (1993). Isolation and characterization of encephalitic bovine herpesvirus type 1 isolates from cattle in North America. Am. J. Vet. Res., 54: 534-539.

11. Ely, R.W.; D’Offay, J.M.; Ruefer, A.H.; Cash, C.Y. (1996). Bovine herpesviral encephalitis: a retrospective study on archived formalinfixed, paraffin-embedded brain tissue. J. Vet. Diag. Invest., 8: 487492.

12. Fauquet, C.M.; Mayo, M.A.; Maniloff, J.; Desselberger, U.; Ball, L.A. (2004). Virus Taxonomy. The eighth report. Academic Press, San Diego, p.1162.

13. Giavedoni, L.D.; Ruiz, M.; Fijtman, N.; Schudel, A.A.; Rodriguez, M. (1988). Rapid diagnosis of bovine herpesvirus encephalitis: comparasion of nucleic acid hybridization and immunoperoxidase methods using clinical samples. J. Vet. Med., 35: 280-285.

14. Gomes, L.I.; Rocha, M.A.; Costa, E.A.; Lobato Z.I.P.; Mendes, L.C.N.; Borges, A.S.; Leite, R.C.; Barbosa-Stancioli, E.F. (2002) Detecção de herpesvírus bovino 5 (BoHV-5) em bovinos do Sudeste Brasileiro. Arq. Bras. Med. Vet. Zootec., 54: 217-220.

15. Martin, S.W.; Bonnet, B. (1987). Clinical epidemiology. Can. Vet. J., 28: 318-325.

16. MAPA (2005). Boletim da Defesa Sanitária Animal, DSA, SDA, Ministério da Agricultura, Pecuária e Abastecimento, Brasil. http:// www.agricultura.gov.br/portal/page?_pageid=33,3271386\&_dad= portal\&_schema=PORTAL

17. Radostitis, O.M.; Gay, C.C.; Blood D.C.; Hinchcliff, W. (2000). Veterinary Medicine. A textbook of diseases of cattle, sheep, goats and horses. 9 $^{\text {th }}$ edition. WB Saunders, London, UK.

18. Ros, C.; Riquelme, M.E.; Forslund, K.Ö.; Belák, S. (1999). Improved detection of five related ruminant alphaherpesviruses by specific amplification of viral genomic sequences. J. Virol. Meth., 83: 55-65.

19. Roehe, P.M.; Silva, T.C.; Nardi, N.B.; Oliveira, L.G.; Rosa, J.C.A (1997). Diferenciação entre os vírus da rinotraqueíte infecciosa bovina (BHV-1) e vírus da encefalite bovina (BHV-5) com anticorpos monoclonais. Pesq. Vet. Bras., 17: 41-44.

20. Salvador, C.S.; Lemos, R.A.A.; Riet-Corrêa, F.; Roehe, P.M.; Osório, A.L.A.R. (1998). Meningoencefalite em bovinos causada por herpesvírus bovino-5 no Mato Grosso do Sul e São Paulo. Pesq. Vet. Bras., 18: 76-83.

21. Sambrook, J.; Russel, D.W. (2000). Molecular Cloning. A Laboratory Manual. $3^{\text {th }}$ edition. Cold Spring Harbor Laboratory Press, New York, USA, 999 p.

22. Souza, V.F.; Melo, S.V.; Esteves, P.A.; Schmidt, C.S.; Gonçalves, D.A.; Schaefer, R.; Silva, T.C.; Almeida, R.S.; Vicentin, F.; Franco, A.C.; Oliveira, E.A.; Spilki, F.; Weiblen, R.; Flores, E.F.; Lemos, R.A.; Alfieri, A.A.; Pituco, E.M.; Roehe, P.M. (2002). Caracterização de herpesvírus bovinos tipos 1 (BHV-1) e 5 (BHV-5) com anticorpos monoclonais. Pesq. Vet. Bras., 22: 13-18. 
Alfieri, A.A. et al.

23. Takiuchi, E.; Médici, K.C.; Alfieri, A.F.; Alfieri, A.A. (2003). Otimização da reação em cadeia pela polimerase (semi-nested PCR) para a detecção do herpesvírus bovino tipo $1 \mathrm{em}$ fragmentos de órgãos fetais e em sêmen de bovinos naturalmente infectados. Semina: Ci. Agr., 24: 43-56.
24. Takiuchi, E.; Médici, K.C.; Alfieri, A.F.; Alfieri, A.A. (2005). Bovine herpesvirus type 1 abortions detected by a semi-nested PCR in Brazilian cattle herds. Res. Vet. Sci., 78: 85-88. 